Research Article

\title{
INFLUENCE OF SPRING SEASON CROP RESIDUE ON PRODUCTIVITY OF RICE-WHEAT CROPPING SYSTEM
}

\author{
K. P. Devkota ${ }^{1}$, D. N. Yadav $^{2}$, N. K. Chaudhary ${ }^{2}$, D. R. Dangol ${ }^{3}$ and K. B. Basnet ${ }^{2}$ \\ ${ }^{1}$ LI-BIRD, Chitwan and ${ }^{2}$ Institute of Agriculture and Animal Sciences, Rampur, Chitwan, Nepal \\ Email:kdgorkha@yahoo.com
}

\begin{abstract}
A field experiment was conducted to determine the effect of cultivation and plant residue incorporation of blackgram [Vigna mungo (L.) Hepper], mungbean [Vigna radiata (L.) Wilczek], cowpea (Vigna sinensis L.), maize (Zea mays L.) and maize+blackgram on response of rice to two levels ( 0 and $90 \mathrm{~kg} \mathrm{ha}{ }^{-1}$ ) of nitrogen and their residual effects on nitrogen management of subsequent wheat crop. The experiment was carried out in Randomized Complete Block design in spring, Split Plot design in rainy, and Split-Split plot design in winter seasons of 2000 at Institute of Agriculture and Animal Science (IAAS), Rampur, Chitwan, Nepal. Results showed that cultivation and incorporation of different spring season crop's (legume and cereal) residue into the soil did not significantly affect rice yield. Such trend was also observed on wheat grain yield when spring season crops were followed by rice in a sequential cropping system. Significantly higher $(\mathrm{p}<0.001)$ rice equivalent yield $\left(6.56 \mathrm{tha}^{-1}\right)$ and net profit (Rs. $\left.46489 \mathrm{ha}^{-1}\right)$ were obtained under mungbean-rice sequence. Similarly, significantly higher $(\mathrm{p}<0.001)$ wheat equivalent yield $\left(8.74 \mathrm{t} \mathrm{ha}^{-1}\right)$ and net profit $\left(\mathrm{Rs} .44811 \mathrm{ha}^{-1}\right)$ were obtained under mungbean-rice-wheat sequence. Significantly higher yield of rice was obtained under $90 \mathrm{~kg} \mathrm{~N} \mathrm{ha}{ }^{-1}$ compared to control and had significant residual effect of $\mathrm{N}$ on wheat grain yield. Nitrogen topdressed at crown root initiation (CRI) and panicle initiation (PI) stages did not influence significantly on the grain yield of wheat. Therefore, for the long term sustainability of rice-wheat cropping system, inclusion of mungbean in the spring (fallow) season could be considered promising practice.
\end{abstract}

Key words: Rice-wheat cropping system, sustainability, residue incorporation, nitrogen

\section{INTRODUCTION}

With the release of high yielding fertilizer responsive varieties of wheat in the late sixties and that of rice in the early seventies, the cropping pattern has made a distinct shift in favor of "Rice-Wheat" multiple cropping system in Nepal, India and Pakistan, particularly in areas well endowed with assured irrigation (Katyal et al., 1998). Rice-wheat is the predominant cropping system in the Terai and mid-hills of Nepal, as rice and wheat occupy approximately $54 \%$ of total area devoted for cereal production while about 35\% of total rice and $84 \%$ of total wheat area in the country fall in rice-wheat system in Nepal (Giri, 1995). However, sustainability of this system has been questioned as there are reports of yield stagnation and a decline in the increment in productivity with fertilizer applications (Yadav et al., 1998). The reasons for yield stagnation and decline are not fully understood. Being a cereal system, it exploits the soil to a greater extent making it poorer year after year (Chandra et al., 2001). The rice-wheat system accounts for annual removal of more than $650 \mathrm{~kg} \mathrm{ha}^{-1}$ of $\mathrm{N}, \mathrm{P}$ and $\mathrm{K}$ resulting in negative balance of N, P and K even with recommended fertilizer use which adversely affecting the sustainability of production system (Abrol et al., 1998).

Among the major nutrients, nitrogen is the key input limiting rice production. The efficiency of applied nitrogen in rice is approximately $33 \%$ only and even with the best agronomical practices the recovery seldom exceeds 60-65\% of the total applied nitrogen (De Datta, 1981). Legumes can contribute significantly to achieve the twin objectives of increasing productivity and improving the sustainability of the rice and wheat based cropping systems (Yadav et al., 1998). The legumes grown together with or before a cereal crop can reduce and sometimes substitute the need of nitrogen application as well. The deleterious effect of spring fallow on soil physical and chemical properties, soil organic carbon content and soil fertility can be decreased by cultivating legume crops during fallow period (Mahapatra and Sharma, 1995). On the other hand there is scope of increasing per capita availability of protein to rural poor population by the introduction of legumes in the fallow during dry season (Gangwar et al., 1990). 
Out of three seasons, i.e. spring, rainy and winter in Nepal, spring is the dullest season considering agricultural production. Since rice is grown during the rainy season (June/July to October/November), and wheat from winter to spring seasons (mid November to mid April), about 70 to 80 days time is available from mid April to the end of June for growing short duration legumes. During this period, either growing of various short duration crops, such as cowpea, blackgram, mungbean, maize is possible or the land has to leave fallow. Those crops can give production in 60-90 days, which also offer manurial value when their plant residues are incorporated into the soil. A study was, therefore, undertaken with the objectives to determine the effect of different spring season crops with all aboveground vegetative mass (after grain removal) incorporation into soil on the productivity of rice and wheat crops, to evaluate the response of rice to different levels of $\mathrm{N}$ after spring season crops and to identify the response of no tilled wheat to time of $\mathrm{N}$ application and crop sequences.

\section{MATERIALS AND METHODS}

\section{Site and experimental design}

The experiment was conducted at Institute of Agriculture and Animal Science, Rampur, Chitwan, Nepal during 2000. The soil was sandy loam with an organic $\mathrm{C}$ content of $24 \mathrm{~g} \mathrm{~kg}^{-1}$ soil, total $\mathrm{N}$ content of $0.16 \%$, available phosphorus $92.50 \mathrm{~kg} \mathrm{ha}^{-1}$, available potassium $126.34 \mathrm{~kg} \mathrm{ha}^{-1}$, and $\mathrm{pH} 6.1$ in the top $15 \mathrm{~cm}$ depth before experimentation. The site received rainfall of $955 \mathrm{~mm}$ during 2000. The experiment was conducted using a simple Randomized Complete Block design in spring season, Split Plot design in rainy season and SplitSplit Plot design in winter season with three replications for all the experiments. In the spring season, six crops, i.e. blackgram, mungbean, cowpea, maize, maize+blackgram and fallow, were grown each in an area of 28.56 $\mathrm{m}^{2}$. During rainy season, the main plots were splitted into two sub-plots $\left(13.60 \mathrm{~m}^{2}\right.$ area) and 0 and $90 \mathrm{~kg} \mathrm{~N}$ $\mathrm{ha}^{-1}$ were applied as the sub plot treatments. In winter season, the sub plots were further splitted into two subsub plots $\left(6.46 \mathrm{~m}^{2}\right.$ area) to study the effect of time of $\mathrm{N}$ application i. e. (i) $1 / 2 \mathrm{~N}$ as basal and $1 / 2 \mathrm{~N}$ at crown root initiation and (ii) $1 / 2 \mathrm{~N}$ as basal and $1 / 2 \mathrm{~N}$ at panicle initiation stage. In both treatments $\mathrm{P}$ and $\mathrm{K}$ were applied as basal dressing.

\section{Crop management}

In spring season, in pure legume, diammonium phosphate @ $100 \mathrm{~kg} \mathrm{ha}^{-1}$ and muriate of potash @ $50 \mathrm{~kg}$ $\mathrm{ha}^{-1}\left(18: 46: 30 \mathrm{~kg}\right.$ NPK ha $\left.{ }^{-1}\right)$ were placed in line as basal dose. The pure maize and intercrop maize crops were fertilized with 60:30:30 kg NPK ha-1. The varieties used for blackgram, mungbean, cowpea and maize were Type-19, NCM-5, Akash, and Arun-2, respectively. The spacing for legume crops was 30x10 $\mathrm{cm}^{2}$ and for maize $60 \times 20 \mathrm{~cm}^{2}$. In intercropping, one row of maize was grown with one row of blackgram, i.e. in 1:1 ratio.

In rainy season, the straw of spring season crops left in the plots were chopped into pieces and incorporated into the soil seven days before rice transplanting. Two seedlings of 5 weeks old rice variety Masuli was transplanted in the puddled lowland field at $20 \times 15-\mathrm{cm}^{2}$ spacing. Half of the nitrogen as per individual treatment and full dose of $\mathrm{P}$ and $\mathrm{K}$ at the rate of 60 and $40 \mathrm{~kg} \mathrm{ha}^{-1}$ - were applied as basal dose. The remaining $1 / 2$ quantity of nitrogen was top-dressed at panicle initiation stage.

In winter season, after harvesting rice, weeds remained in the field was removed manually. Surface seeding of pre-sprouted wheat variety NL297@150 kg ha-1 was done in line at $20 \mathrm{~cm}$ row to row distance in a continuous manner and covered with previous year's wheat husk for proper germination. The crop was fertilized with 100:60:40 kg NPK ha ${ }^{-1}$ through urea, diammonium phosphate and muriate of potash. In addition to the total amount of $\mathrm{P}$ and $\mathrm{K}$, half of the nitrogen was broadcasted at the time of sowing, and remaining half dose of nitrogen was top-dressed as per treatment, i.e. one at crown root initiation (CRI) stage and another at panicle initiation (PI) stage.

\section{Statistical analysis}

Rice equivalent yield of different crop sequence was computed by multiplying the grain yield of spring season crops with their respective per unit price. The calculated total return $\left(\mathrm{Rs} . \mathrm{h}^{-1}\right)$ was divided by the price of rice and was added to the rice grain yield. Similarly wheat equivalent yield of different crop sequences was computed by multiplying the grain yield of spring season crops and rainy season rice with their respective per unit price and total return (Rs. ha ${ }^{-1}$ ) was calculated. Total cost of production of each treatment of spring, rainy 
and winter season crops were calculated. Net return was calculated by deducting the cost of cultivation from the gross return of each treatment. Analysis of variance (ANOVA) for all the parameters was done using MSTATC computer statistical program, mean separation was performed using Critical Difference (CD) at 5\% probability level.

\section{RESULTS AND DISCUSSION}

\section{Spring season crops}

There was considerable variation in plant population, dry matter yield, above ground plant $\mathrm{N}$ production and grain yield among the crop species. Intercropping produced more dry matter than respective sole cropping presumably because of the higher seeding rate with the combination of two crops. Similar trend was also found by Sullivan et al. (1991). Blackgram accumulated remarkably higher amount of dry matter $\left(3.93 \mathrm{t} \mathrm{ha}^{-1}\right)$ which contained $83 \mathrm{~kg} \mathrm{~N} \mathrm{ha}^{-1}$ (Table 1). Further, it was followed by cowpea that produced $2.67 \mathrm{t} \mathrm{ha}^{-1}$ of dry matter with $59 \mathrm{~kg} \mathrm{~N} \mathrm{ha}{ }^{-1}$. John et al. (1989) also reported 62 to $74 \mathrm{~kg} \mathrm{~N} \mathrm{ha}^{-1}$ accumulation by approximately 45 day old cowpea (Vigna unguilata L.) grown as green manure. On the other hand, the dry matter accumulation $(3.22 \mathrm{t}$ $\left.\mathrm{ha}^{-1}\right)$ by sole crop of maize was higher than fallow $\left(2.87 \mathrm{t} \mathrm{ha}^{-1}\right)$, but returned lower amount of nitrogen to soil. This may be due to higher content of $\mathrm{N}$ in grasses grown in fallow land compared to maize.

Table 1. Mean of plant population, dry matter yield, aboveground plant $\mathbf{N}$ and grain yield of spring season crops in Rampur, Chitwan, 2000

\begin{tabular}{|lcccc|}
\hline Spring crops & $\begin{array}{c}\text { Plant population } \\
(\mathbf{0 0 0} \text { ha-1) }\end{array}$ & $\begin{array}{c}\text { Dry matter yield } \\
(\mathbf{t} \text { ha-1) }\end{array}$ & $\begin{array}{c}\text { Above ground plant } \\
\text { N (kg ha-1) }\end{array}$ & $\begin{array}{c}\text { Grain yield } \\
(\mathbf{t} \text { ha-1) }\end{array}$ \\
\hline Blackgram & 500 & 3.93 & 83 & 0.32 \\
Mungbean & 380 & 2.15 & 46 & 0.61 \\
Cowpea & 220 & 2.67 & 59 & 0.71 \\
Sole maize & 120 & 3.22 & 19 & 2.57 \\
Maize in blackgram intercrop & 110 & 2.10 & 8 & 2.49 \\
Blackgram in maize intercrop & 360 & 2.01 & 40 & 0.13 \\
Fallow & - & 2.87 & 25 & - \\
\hline
\end{tabular}

The grain yields of sole legume crops ranged from 0.32 to $0.71 \mathrm{t} \mathrm{ha}^{-1}$. The productivity of important legumes in Nepal ranged from 0.5 to $2.5 \mathrm{t} \mathrm{ha}^{-1}$ (CBS, 2002). Cereal crop had higher grain yield than legume crops. Cowpea had the highest productivity $\left(0.71 \mathrm{t} \mathrm{ha}^{-1}\right)$ followed by mungbean $\left(0.61 \mathrm{t} \mathrm{ha}^{-1}\right)$. Sole blackgram has almost double grain yield than intercrop blackgram.

\section{Rainy season rice}

There was no significant difference $(\mathrm{p}>0.05)$ in grain yield of rice due incorporation of plant residues but $90 \mathrm{~kg} \mathrm{~N}$ ha-1 produced significantly higher $(\mathrm{p}<0.01)$ grain yield (Table 2 ). Accordingly the lowest yield was recorded with pre-rice fallow compared to other sole and intercrops. Higher grain yield of rice was produced in pre-season spring season legumes than cereal (maize) incorporated plots. Compared to pre-rice fallow, the maximum $9.8 \%$ increment in rice yield was recorded with cultivation and plant residue incorporation of spring mungbean. $9.6 \%$ increment in rice yield after mungbean residue incorporation was also reported by Hedge (1992).

Pre-rice intercropping of blackgram with maize assisted to increase rice yield by $6.4 \%$ than pre-rice maize. Pandey et al. (1998) also reported that yield of succeeding rice crop could be increased by $20-40 \%$ if legume were used in the previous cropping system than cereal crops. The higher grain yield of rice grown after legumes than after cereals have also reported by Dhiman et al. (2000).

Significantly higher $(\mathrm{p}<0.001)$ rice equivalent yield was obtained under mungbean-rice sequence $(6.56 \mathrm{t}$ $\left.\mathrm{ha}^{-1}\right)$, which was statistically at par only with maize+blackgram-rice sequence $\left(6.26 \mathrm{t} \mathrm{ha}^{-1}\right)$. Application of $\mathrm{N} @$ $90 \mathrm{~kg} \mathrm{ha}^{-1}$ resulted significantly higher rice equivalent yield compared to zero $\mathrm{kg} \mathrm{N}$ ha-1. Net profit was significantly $(\mathrm{p}<0.001)$ the highest (Rs. $46489 \mathrm{ha}^{-1}$ ) when previous crop grown was mungbean (Table 2) followed by Rs. $43341 \mathrm{ha}^{-1}$ when the previous crop was cowpea. While it was the lowest (Rs. $24685 \mathrm{ha}^{-1}$ ) when there was no previous crops grown i.e. if the land left fallow. Saraf et al. (1998) also found substantially increased productivity 
and net profit if legumes were introduced in rice-wheat cropping system. This matches well to the findings of this study.

Table 2. Mean of grain yield, rice equivalent yield and net profit in different spring-rice cropping sequences as affected by different levels of nitrogen

\begin{tabular}{|lccc|}
\hline Treatments & Rice grain yield $\left(\mathrm{t} \mathrm{ha}^{-1}\right)$ & ${\text { Rice equivalent yield }\left(\mathrm{t} \mathrm{ha}^{-1}\right)}$ & Net $_{\text {profit }}\left(\mathbf{R s ~ h}^{-1}\right)$ \\
\hline Previous crops & & & $32544 \mathrm{c}$ \\
Blackgram & 3.56 & $4.90 \mathrm{~d}$ & $46489 \mathrm{a}$ \\
Mungbean & 3.67 & $6.56 \mathrm{a}$ & $43341 \mathrm{ab}$ \\
Cowpea & 3.49 & $6.12 \mathrm{~b}$ & $34574 \mathrm{c}$ \\
Maize & 3.41 & $5.57 \mathrm{c}$ & $39935 \mathrm{~b}$ \\
Maize+blackgram & 3.63 & $6.26 \mathrm{ab}$ & $24685 \mathrm{~d}$ \\
Fallow & 3.34 & $3.39 \mathrm{e}$ & 4086 \\
C.D. at $5 \%$ & $\mathrm{NS}$ & 0.35 & $34940 \mathrm{~b}$ \\
Nitrogen level $\left(\mathrm{kg} \mathrm{ha}^{-1}\right)$ & & & $38916 \mathrm{a}$ \\
0 & $3.23 \mathrm{~b}$ & $5.19 \mathrm{~b}$ & 1904.88 \\
90 & $3.80 \mathrm{a}$ & $5.75 \mathrm{a}$ & 0.17 \\
C.D. at $5 \%$ & 0.17 & & \\
\hline
\end{tabular}

\section{Winter season wheat}

The higher grain yield of wheat obtained was under blackgram-rice-wheat sequence followed by mungbeanrice-wheat (Table 3). Yield obtained under blackgram-rice-wheat sequence was higher than fallow-rice-wheat by $46.0 \%$. Likewise application of $90 \mathrm{~kg} \mathrm{~N} \mathrm{ha}^{-1}$ to the rice did not yield significantly higher grain yield of wheat. Saxena and Yadav (1998) also found that there was no significant residual effect of nitrogen levels given to rice on wheat grain yield. Time of $\mathrm{N}$ top-dressing in wheat season also did not show a definite increment with respect to grain yield thus the treatments effect was not significant. Residual effect of different nitrogen doses applied in rice had significantly affected $(p<0.05)$ wheat equivalent yield, while different methods of nitrogen application did not significantly influence wheat equivalent yield.

Table 3. Grain yield of wheat, wheat equivalent yield and net profit as affected by proceeding crops, level of $\mathbf{N}$ in rice and time of $\mathbf{N}$ application in wheat

\begin{tabular}{|c|c|c|c|}
\hline Treatments & Rice grain yield $\left(\mathrm{t} \mathrm{ha}{ }^{-1}\right)$ & Rice equivalent yield ( $\left.\mathrm{t} \mathrm{ha}{ }^{-1}\right)$ & Net profit $\left(\right.$ Rs ha $\left.^{-1}\right)$ \\
\hline \multicolumn{4}{|l|}{ Previous crops } \\
\hline Blackgram-rice & 1.11 & $6.93 \mathrm{~d}$ & $32442 d$ \\
\hline Mungbean-rice & 0.95 & $8.74 \mathrm{a}$ & $44811 \mathrm{a}$ \\
\hline Cowpea-rice & 0.88 & $8.15 b$ & 41008b \\
\hline Maize-rice & 0.97 & $7.59 \mathrm{c}$ & $33200 \mathrm{~cd}$ \\
\hline Maize+blackgram-rice & 0.74 & $8.18 \mathrm{~b}$ & $36425 c$ \\
\hline Fallow-rice & 0.76 & $4.78 \mathrm{e}$ & $21375 \mathrm{e}$ \\
\hline C.D. at $5 \%$ & NS & 0.41 & 3659 \\
\hline \multicolumn{4}{|l|}{ Nitrogen level $\left(\mathrm{kg} \mathrm{ha}^{-1}\right)$} \\
\hline 0 & 0.95 & $7.11 \mathrm{~b}$ & $33288 b$ \\
\hline 90 & 0.86 & $7.68 \mathrm{a}$ & $36466 a$ \\
\hline C.D. at $5 \%$ & NS & 0.26 & 2244.53 \\
\hline \multicolumn{4}{|l|}{ Time of $\mathrm{N}$-application } \\
\hline 1/2Nbasal+1/2N CRI & 0.95 & 7.45 & 35332 \\
\hline 1/2N basal+1/2 N PI & 0.85 & 7.35 & 34422 \\
\hline C.D. at $5 \%$ & NS & NS & NS \\
\hline
\end{tabular}


Wheat equivalent yield varied significantly $(\mathrm{p}<0.001)$ due to different crop sequences (Table 3$)$. Wheat equivalent yield $\left(8.74 \mathrm{th} \mathrm{h}^{-1}\right)$ under mungbean-rice-wheat sequence was significantly higher $(\mathrm{p}<0.05)$ to all cropping sequences. This indicates that inclusion of mungbean in rice-wheat cropping system could yield the highest production and productivity per unit area. There were significant differences observed in net profit due to different cropping sequences. The net profit under mungbean-rice-wheat cropping sequence was maximum (Rs. $44811 \mathrm{ha}^{-1}$ ) followed by cowpea-rice-wheat system (Rs. $41008 \mathrm{ha}^{-1}$ ), which was significantly higher than the other crop sequences. Net profit obtained from different times of nitrogen application in wheat was not significantly different $(\mathrm{p}>0.05)$.

\section{CONCLUSIONS}

Inclusion of mungbean followed by cowpea in the rice-wheat cropping system found more profitable. In 70-80 days time spring fallow (i.e. after wheat and before rice) mungbean, cowpea, maize, maize+blackgram and blackgram can be grown in Terai region of Nepal. But it is very difficult to successfully harvest blackgram due to coincidence of blackgram maturity and initiation of monsoon. Maize can be successfully harvested but being cereal-cereal system throughout the year, soil will be exhausted rapidly. Mungbean followed by cowpea is the most promising sequence for that season to increase the production, productivity and sustainability of ricewheat cropping system. Rice-wheat-fallow system can be converted into profitable cropping system and thus spring fallow can be eliminated. Thus the finding of this study conclude that rice-wheat-mungbean followed by rice-wheat-cowpea cropping system is the most profitable, productive and sustainable cropping for Terai region of Nepal.

\section{ACKNOWLEDGEMENTS}

The assistantship awarded to the first author by Rice-Wheat System Project (Soil Management CRSP/ Cornell University, USA) to conduct this study is gratefully acknowledged.

\section{REFERENCES CITED}

Abrol, I. P., K. F. Bronson, J. M. Duxbury and R. K. Gupta. 1998. Long-term soil fertility experiments in rice-wheat cropping systems. Proceedings of Workshop. Surajkund, Haryana, 15-18 Oct. 1996. Rice-Wheat Consortium Indo-Gangetic Plains, New Delhi, India.

CBS. 2002. Statistical year book of Nepal. His Majesty's Government of Nepal. Central Bureau of Statistics, Kathmandu, Nepal.

Chandra, S., B. N. Ghosh, P. Singh and R. D. Singh. 2001. Effect of varying fertilization on yield of rice (Oryza sativa)-wheat (Triticum aestivum) system and soil fertility status. Indian J. Agric. Sci. 71(10):631-633.

De Datta, S. K. 1981. Principles and practices of rice production. John Wiley and Sons, New York.

Dhiman, S. D., D. P. Nandal, Hariom and D. S. Mehla. 2000. Productivity and economic feasibility of rice (Oryza sativa)-based cropping systems in North-Western India. Indian J. Agric. Sci. 70(9):571-573.

Gangwar, B., A. D. Mongia and A. K. Bandhyopadhyay. 1990. Rice based cropping systems for Bay Islands. Research Bulletin No. 2, Central Agricultural Research Institute, Port Blain. pp. 8-22.

Giri, G. S. 1995. The effect of rice culture on subsequent wheat grain yield. In: R. N. Devkota and E. E. Saari (eds.) Proc. Wheat Research Reports. National Winter Crop Technology Workshop. Sept. 7-10, 1995. NARC/CIMMYT, National Wheat Research Progaramme, Siddharthanagar, Bhairahawa. pp. 415-419.

Hedge, D. M. 1992. Cropping systems research highlights. In: Coordinators report, $20^{\text {th }}$ Workshop, Tamil Nadu Agricultural University, Coimbator, 1-4 June 1992. Modipuram, Meerut 250 110, India. pp. 21-22.

John, P. S., R. K. Pandey, R. J. Buresh and R. Prasad. 1989. Lowland rice response to urea following three cowpea cropping systems. Indian Agron. J. 81: 853-857.

Katyal, V., S. K. Sharma and K. S. Gangwar. 1998. Stability analysis of rice (Oryza sativa)-wheat (Triticum aestivum) cropping system in integrated nutrient management. Indian J. Agric. Sci. 68(2):51-53.

Mahapatra, B. S. and G. L. Sharma. 1995. Effect of spring season legumes on growth and yield of low land rice (Oryza sativa) and it's residual effect on succeeding wheat (Triticum aestivum) in rice-wheat system. Indian J. Agric. Sci. 65(8): 557-561. 
Pandey, S. P., S. Bhattarai, N. K. Rajbhandari, R. P. Sha and S. P. Sapkota. 1998. Overview and prospects for increasing residual benefits of legumes in rice and wheat cropping system in Nepal. In: Proceedings of Residual Effects of Legumes in Rice and Wheat Cropping Systems of the Indo-Gangetic Plains. ICRISAT, India.

Saraf, C. S., O. P. Rupela, D. M. Hedge, R. L. Yadav, B. G. Shivakumar, S. Bhattaria, M. A. Razzaque and M. A. Sattar. 1998. Biological nitrogen fixation and residual effects of winter grain legumes in rice and wheat cropping systems of the Indo-Gangetic plain. In: Proceedings of Residual Effects of Legumes in Rice and Wheat Cropping Systems of the Indo-Gangatic Plains. ICRISAT, India.

Saxena, A. and D. S. Yadav. 1998. Effect of summer greengram (Phaseolus radiatus) on rice (Oryza sativa)-wheat (Triticum aestivum) system. Indian J. Agric. Sci. 68(9): 583-586.

Sullivan, P. G., D. J. Parrish and J. M. Luna. 1991. Cover crop contribution to N supply and water conservation in corn production. American J. Altern. Agric. 6:106-113.

Yadav, R. L., D. S. Yadav, R. M. Singh and A. Kunwar. 1998. Long-term effects of inorganic fertilizer inputs on crop productivity in rice-wheat cropping system. Nutrient Cycling in Agro-ecosys. 51:193-200. 